\title{
APSA President-Elect John Ishiyama: Teacher-Scholar and Advocate for Inclusion
}

\author{
OKIYOSHI (OKI) TAKEDA | CO-CHAIR, ASIAN PACIFIC AMERICAN CAUCUS \\ NGOC PHAN | CO-CHAIR, ASIAN PACIFIC AMERICAN CAUCUS \\ KIM GERON | CHAIR, COMMITTEE ON THE STATUS OF ASIAN PACIFIC AMERICANS IN THE PROFESSION \\ ANDY AOKI | AUGSBURG UNIVERSITY \\ JAMES S. LAI | SANTA CLARA UNIVERSITY \\ LOAN LE | SAN FRANCISCO STATE UNIVERSITY \\ PEI-TE LIEN | UNIVERSITY OF CALIFORNIA, SANTA BARBARA
}

imp

ncoming APSA president John Ishiyama is a teacher-scholar whose term truly honors the first part of that appellation. Although his term as APSA president is just beginning, he has long been a leader in our discipline. His scholarly record is impressive, but his contributions to the field of political science education may be his most critical accomplishment as traditional higher education confronts an uncertain future.

In 2002, John became president of what was then known as the Undergraduate Education Section of APSA. In the ensuing years, he helped to greatly expand the discipline's attention to teaching and learning. Not only did this help our profession keep abreast of larger national movements, it also laid the groundwork for what may be critical for our future. As the liberal arts struggles to justify itself in the face of multiple existential threats, we presumably have a major contribution to make in the field of civic education.

Doing so, however, will require that teaching and learning be much more than an afterthought, and John has played a central role in bolstering the discipline's attention to this critical area.

One of the key ways he has helped do this is through his leading role in the creation of the APSA Teaching and Learn-

Okiyoshi (Oki) Takeda is professor of political science at Aoyama Gakuin University. He conducts research in Quantitative and Qualitative Social Research, Legislative Studies, and Asian American Studies.

Ngoc Phan is assistant professor of political science at Hawaii Pacific University. She is an expert in the areas of American Politics, Political Behavior, Political Psychology, and Race and Ethnicity.

Kim Geron is emeritus professor of political science at California State University East Bay, where he teaches courses in public policy and public administration, and conducts research on racial politics, labor, and immigration.

Andy Aoki is professor of political science at Augsburg University. He was a cofounder of the Asian Pacific American Caucus and has published work on immigration, Asian American and other ethnoracial politics, multicultural education, and popular culture and politics. ing Conference (TLC), which was first convened in 2004. While teaching had long been the subject of discussion at conferences, it was something that often had to be squeezed into hallway chats on the way from one panel to another, or over dinner at the end of the day. The TLC created a space where this critical activity would be the central focus.

John also was central in the creation of the Journal of Political Science Education, which also began in 2004. The journal's first editor, John served in that role until 2012, helping to create a scholarly ecosystem that could help support political scientists who wanted to research teaching and learning.

John has been a leader in other efforts to expand the discipline. From 2011-2013 he was co-chair of the Asian Pacific American Caucus, one of a network of groups that has pushed for a more inclusive profession. With an association that has not always been supportive of such groups, John has continued to help expand spaces, helping to connect diversity efforts with his other areas of interest, illustrated in his tireless efforts to help assemble a special issue on teaching about Asian and Pacific Islander Americans.

His concern with greater inclusion can be seen in many other areas, notably his efforts to support students from historically underrepresented groups and first-generation college students. While he was at Truman State, he helped lead the university's McNair programs, serving as director from 2004-2008. In more recent years, he has served as the principal investigator of a National Science Foundation Research Experience for Undergraduates grant, drawing students from across the country.

James S. Lai is professor of ethnic studies and political science at Santa Clara University. His research interests and specialties include US racial and ethnic politics, urban politics, multiracial coalitions, California local politics, and Asian American politics.

Loan Le is president and CEO of the Institute for Good Government and Inclusion (IGGI).

Pei-te Lien is professor of political science at the University of California, Santa Barbara. Her primary research interest is the political participation and representation of Asian and other nonwhite Americans. 
With his extensive record of service, it is remarkable that John has also assembled such an extensive publication record, with eight books and over 150 scholarly articles and book chapters. His scholarship is wide-ranging, covering democratization, political parties, ethnic politics and, of course, the scholarship of teaching and learning. His scholarship in the latter includes several scholarly articles on assessment. A significant portion of John's research has been in comparative politics, where he has also been a leader, including serving as the president of the International Studies Association Midwest.

His role as lead editor and editor-in-chief of the American Political Science Review (from 2012-2016) is another sign of the scholarly respect he has in our discipline. During those years, John helped to establish guidelines for Data Access and Research Transparency (DART). With the wide range of research activity undertaken by political scientists, this was a very difficult process, but forces well beyond our discipline were insisting that business as usual was not acceptable, and John worked diligently to try to respond to the wide range of concerns.

John's receipt of the 2018 Frank J. Goodnow award also testifies to his many contributions to our profession. In addition to his editorial leadership of the APSR and the Journal of Political Science Education, he serves or has served on the editorial boards of numerous other scholarly journals, held leadership positions in multiple professional associations, and continued his work to help improve our teaching efforts. In recent years he has been working on a project that seeks to re-envision the undergraduate political science major.

Given John's interests, it almost goes without saying that his career is dedicated to teaching and mentoring. His University of North Texas colleagues are convinced that he seldom sleeps, given his proclivity for sending emails at all hours of the night, communicating with professional colleagues and coauthors, but also with former and current students who live and work all over the world.

John's place as the first Asian American president of APSA has great symbolic importance, but it is his long list of accomplishments and his influence which have brought him to this position. One of his UNT colleagues, Val Martinez, summarizes it well: "His intellect, energy, patience, and enthusiasm for new ideas and new experiences draws people to John and it is very safe to say that John's influence is truly global," adding "I would be remiss if I failed to mention that he is fun to hang out with." Those of us know John can all attest to that as well.

Loan Le, who organized the WPSA Mini-Conference on Asian Pacific American Politics, was impressed by John's style of leadership by example when he made time to attend much of and delivered inspiring remarks at the 2021 virtual gathering in early April. In a time when APAs are targets of hate crime across the country, Loan believed that this demonstrates his love for, devotion to, and support for teaching and learning APA politics beyond his demanding APSA work, as well as much-needed vision for our field and community.

Pei-te Lien has recently worked with John (and Sherri Wallace) on a conference theme for the 2022 APSA meeting which she will co-chair. Whereas she only has limited experience working directly with John, she said she could attest to John's super effective management style and skills in advance planning. "There's pressure, but not high enough to make you feel uncomfortable," she said. The fact that she would agree to take on a leadership role in a second annual meeting of the same year also showcased John's unmatched communication/persuasion skills.

Kim Geron, chair of the Committee on the Status of Asian Pacific Americans in the Profession noted in addition to John's numerous academic and professional accomplishments, his consistent support for inclusion and equity for APAs and others historically underrepresented in the field of political science is much appreciated and we look forward to working together during this incredibly challenging political movement as he takes on a new role as APSA President.
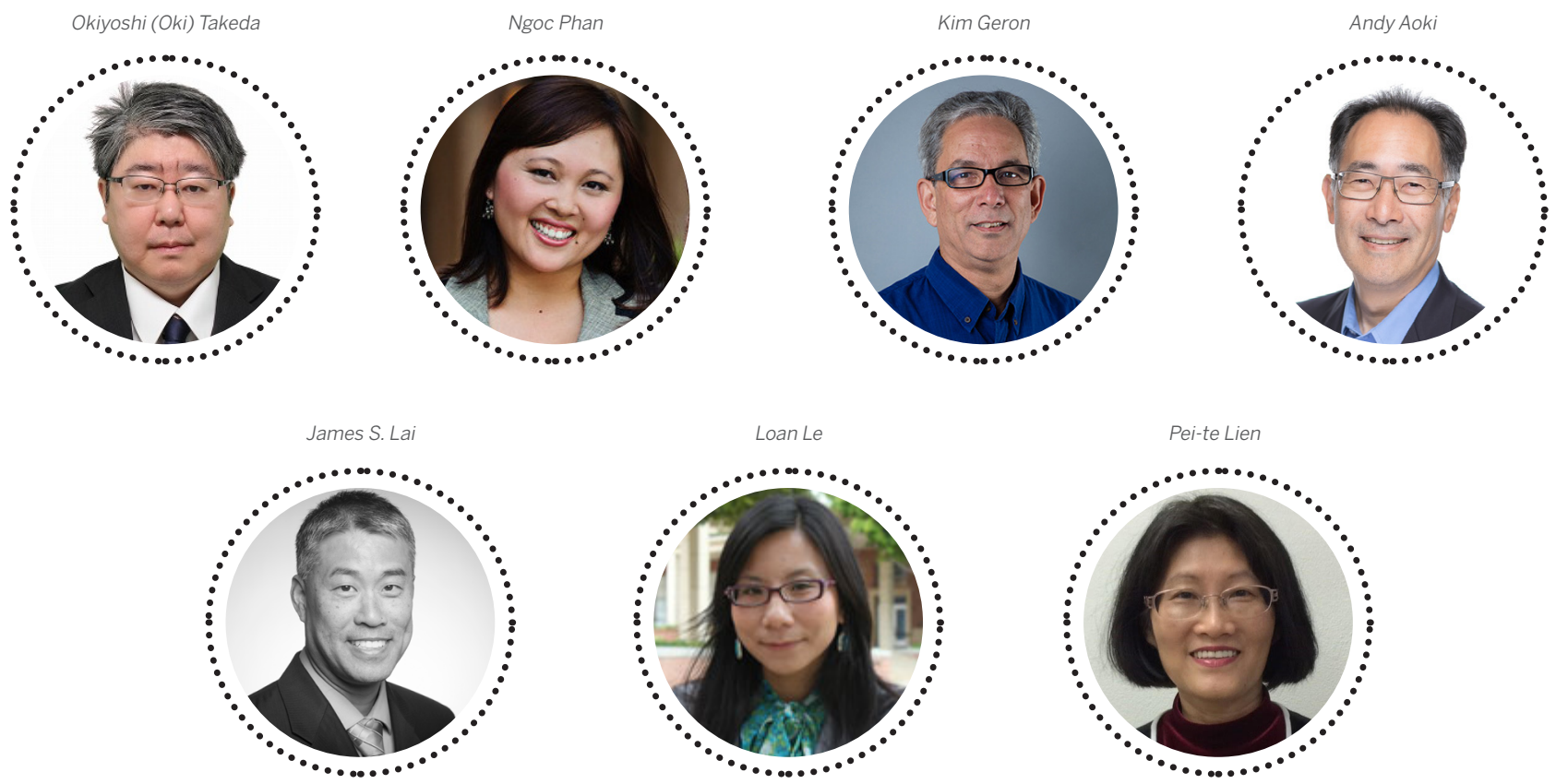


\section{CALL FOR EDITORS: JOURNAL OF POLITICAL SCIENCE EDUCATION}

\section{APPLICATIONS DUE SEPTEMBER 1, 2021}

The American Political Science Association (APSA) invites applications and nominations for editorship of the Journal of Political Science Education (JPSE) to begin a term on August 1, 2022. Since 2017, APSA has been the official sponsor of JPSE, which is made available to the 10,000 members of the association. The journal currently receives approximately 120 submissions per year from all areas of political science education, including scholarship of teaching and learning, political science instruction, teaching, book and resource reviews, and reflections.

JPSE is an intellectually rigorous, peer-reviewed journal that publishes evidence-based and theoretically informed scholarship on teaching and pedagogical issues in political science. It aims to represent a full range of empirical and philosophical questions, issues, and approaches relevant to political science education at the two-year community college, four-year college, university, master's, and $\mathrm{PhD}$ levels. The journal supports research that engages with the broad scholarship of teaching and learning and improves the quality of teaching and learning in the discipline.

The editorship is a four-year term beginning on August 1, 2022, with the possibility of a twoyear renewal with the approval of the APSA Council. A Search Committee has been formed to help select the editor, who will then be submitted to the Publications Committee for APSA Council approval, and the selected applicant(s) will be contacted shortly thereafter. We welcome applications from all interested parties and nominations of qualified candidates. Please direct any questions or nominations to Jon Gurstelle, APSA Publishing Director at jgurstelle@apsanet.org or Amanda Rosen, Chair of the Search Committee at amanda.rosen@ usnwc.edu. Applications should be submitted to Jon Gurstelle at jgurstelle@apsanet.org.

The deadline for applications is September 1, 2021.

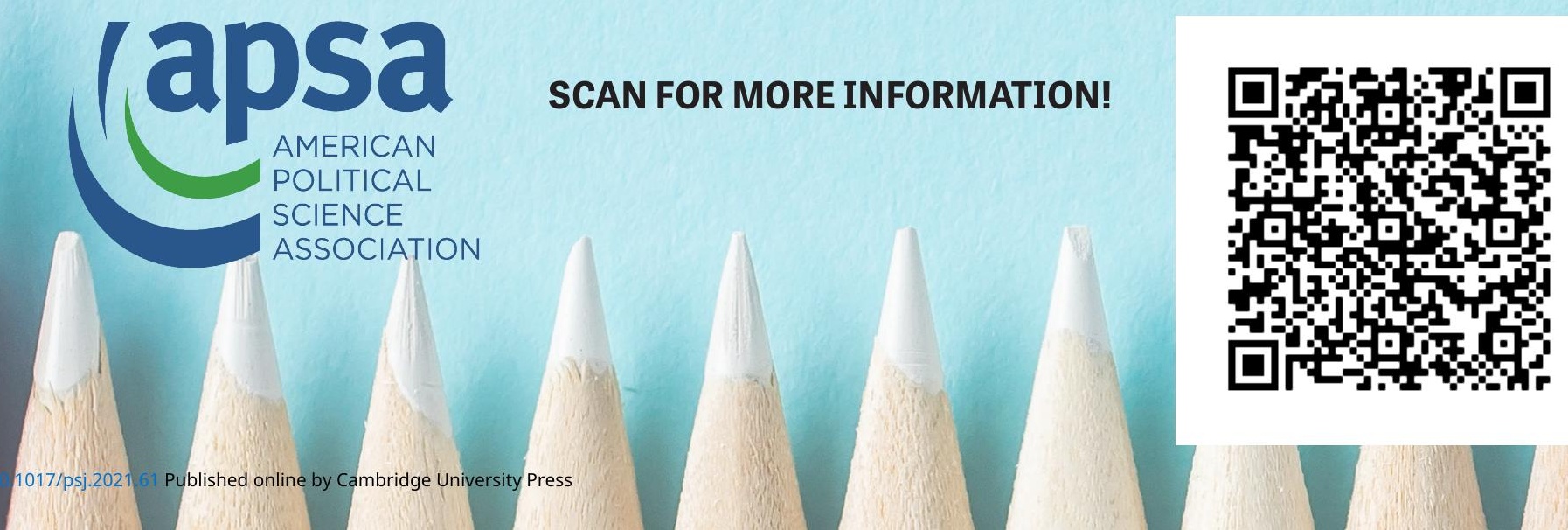

